\title{
Pemikiran diskursif amanat agung Injil Matius 28:18-20
}

\section{Agus Surya ${ }^{1}$, Setinawati ${ }^{2}$}

1,2Insitut Agama Kristen Negeri Palangka Raya, Kalimantan Tengah

19agus080311@gmail.com, 2setinawatistn@gmail.com

\begin{tabular}{|c|c|}
\hline $\begin{array}{l}\text { Article History } \\
\text { Submitted: } \\
\text { December, } 16,2020 \\
\text { Revised: } \\
\text { March, } 25,2021 \\
\text { Accepted: } \\
\text { April, } 01,2021\end{array}$ & $\begin{array}{l}\text { Abstract: This paper presents the discursive thinking of the Great Commission } \\
\text { of Matthew 28:18-20. A correct understanding of the Great Commission is } \\
\text { needed so that the implementation of the preaching of the gospel in society is } \\
\text { not arbitrary, let alone cause conflict. This study in exploring the discursiveness } \\
\text { of the Great Commission was conducted using a qualitative approach. Retrieval } \\
\text { of data in the literature related to the topic in this paper. This research } \\
\text { concludes that the discursive Great Commission of the Lord Jesus Christ is one }\end{array}$ \\
\hline $\begin{array}{l}\text { Keywords: } \\
\text { discursive } \\
\text { thinking; } \\
\text { great } \\
\text { commission; }\end{array}$ & $\begin{array}{l}\text { of the culmination of all the biblical foundations for evangelism to develop faith } \\
\text { that comes from the four Gospels and the Acts of the Apostles with different } \\
\text { emphases. The results of the study conclude that the Gospel of Matthew 28:18- } \\
20 \text { emphasizes that disciples who are weak in faith are empowered to } \\
\text { evangelize with the promise of God's participation until the end of time. }\end{array}$ \\
\hline $\begin{array}{l}\text { Matthew } 28 \\
\text { amanat agung; } \\
\text { Matius } 28 ; \\
\text { pemikiran } \\
\text { diskursif }\end{array}$ & $\begin{array}{l}\text { Abstrak: Tulisan ini menyajikan pemikiran diskursif Amanat Agung Matius } \\
\text { 28:18-20. Pemahaman yang benar tentang Amanat Agung diperlukan agar } \\
\text { implementasi pemberitaan Injil di masyarakat tidak sembarangan, terlebih } \\
\text { menyebabkan konflik. Kajian dalam mendalami diskursif Amanat Agung ini } \\
\text { dilakukan dengan pendekatan kualitatif. Pengambilan data secara literatur ter- } \\
\text { kait topik dalam tulisan ini. Penelitian ini menyimpulkan, diskursif Amanat } \\
\text { Agung Tuhan Yesus Kristus adalah salah satu puncak dari semua dasar Alkitab } \\
\text { bagi pekabaran Injil untuk menumbuh kembangkan iman yang bersumber pada } \\
\text { ke empat Injil dan Kisah Para Rasul dengan penekanan yang berbeda-beda. } \\
\text { Hasil penelitian menyimpulkan bahwa Injil Matius } 28: 18-20 \text { menekankan, para } \\
\text { murid yang dalam keadaan lemah iman diberi kuasa untuk melakukan } \\
\text { penginjilan dengan janji penyertaan Tuhan sampai akhir zaman. }\end{array}$ \\
\hline
\end{tabular}

\section{Pendahuluan}

Salah satu dasar Amanat Agung adalah perintah Tuhan Yesus Kristus. Kata perintah dalam Alkitab bahasa Yunani adalah entello yang berarti perintah untuk bergabung dengan sesuatu, atau perintah untuk terikat pada sesuatu. ${ }^{1}$ Konteksnya jelas yaitu bergabung dan terikat pada misi Amanat Agung Tuhan Yesus Kristus, yang menjadi puncak dari semua dasar Alkitab bagi misi. Misi Amanat Agung tersebut berasal dari lima sumber yaitu empat Injil (Mat. 28:19-20; Mrk. 16:14-18; Luk. 24:44-49; Yoh. 20:19-23); dan Kisah Para Rasul (Kis. 1:8). Tiap sumber tersebut memiliki tekanan dan keistimewaan yang berbeda seperti yang ingin disampaikan penulisnya. ${ }^{2}$

${ }^{1}$ Hasan Susanto, Perjanjian Baru Interlinier Yunani-Indonesia Dan Korkondansi Perjanjian Baru (PBIK) - Jilid 1 (Jakarta: Lembaga Alkitab Indonesia (LAI), 2006).

${ }^{2}$ Putranto BE, Misi Kristen (Yogyakarta: Andi Offset, 2017), 58. 
Amanat Agung Tuhan Yesus menggunakan bentuk partisip yang menyatakan tindakan bersamaan antara kata pergi dan memberitakan. Hagelberg menjelaskan penekanan Amanat Agung pada Matius 28:17-20 adalah sebagai berikut: ${ }^{3}$ pertama, para murid dalam keadaan lemah iman untuk melakukan misi penginjilan. Hal ini terlihat dari latar belakang situasi pada waktu itu. Para murid dalam keadaan takut, ketidakpastian, bingung, masih memiliki pola pikir yang keliru terhadap kematian Tuhan Yesus di salib. Hal ini dinyatakan oleh Matius bahwa beberapa murid ragu-ragu (Mat. 28:17).

Kedua, para murid mendapat kuasa untuk melakukan misi dan sekaligus memperlengkapi pemberitaan. Tuhan memahami kelemahan para murid, dan tidak mempunyai kemampuan untuk melaksanakan misi. Oleh karena itu Tuhan memberi kuasa kepada para murid untuk melakukan misi pemberitaan Injil (Mat. 28:18). Ketiga, para murid diarahkan pada sasaran misi "Baptislah mereka dalam nama Bapa dan Anak dan Roh Kudus dan ajarlah mereka melakukan segala sesuatu yang telah Kuperintahkan kepadamu" (Mat. 28:19-20). Keempat, para murid mendapat jaminan penyertaan Kristus sampai akhir zaman, ini menyatakan bahwa amanat melakukan misi serius dan harus dilaksanakan. Namun tidak berarti apa yang telah disampaikan oleh Tuhan Yesus selama pelayanan-Nya tidak penting/ tidak terlalu serius atau tidak se-agung Amanat Agung dalam keempat Injil dan Kisah Para Rasul. Dalam pemikiran tulisan ini ingin mengajak para pembaca juga tidak mengurangi kadar perkataan/ pemikiran Tuhan Yesus oleh karena telah tergeser oleh istilah Amanat Agung. Akan tetapi juga perlu menyampaikan bahwa perkataan Tuhan Yesus dalam Matius 28:18-20 perlu diperhatikan dan dikerjakan sesuai pemaknaan baru yang akan dijelaskan dalam artikel ini.

Amanat agung Tuhan Yesus Kristus pada ayat-ayat tersebut di atas, menggunakan bentuk partisip yang dilakukan secara terus-menerus. ${ }^{4}$ Setiap orang percaya, mau atau tidak mau, suka atau tidak suka, memiliki kewajiban untuk melaksanakan Amanat Agung Tuhan Yesus Kristus. Oni menegaskan bahwa Amanat Agung Tuhan Yesus Kristus bukan suatu pilihan tetapi keharusan untuk dilaksanakan. Berita yang harus disampaikan adalah bahwa Yesus Kristus telah mati, dikuburkan, dan pada hari ketiga Ia bangkit dan naik ke sorga. ${ }^{5}$ Jadi, setiap orang percaya atau gereja yang tidak mau melaksanakan misi Amanat Agung Tuhan Yesus Kristus berarti menolak perintah Yesus Kristus.

Amanat agung melekat dalam diri gereja. Hal ini karena gereja bertanggungjawab penuh dalam melaksanakan misi Allah. ${ }^{6}$ Dalam memenuhi tugas panggilan tersebut, kehadiran gereja belumlah cukup, tetapi masih harus ditekankan lagi segi pemberitaan lewat perkataan dan perbuatan. Lebih lanjut dikatakan bahwa tantangan misi Amanat Agung Tuhan Yesus pada masa kini adalah kesalahan memahami dan menafsirkan kata misi itu sendiri. Sebagai akibat terjadilah pergeseran penekanan wawasan misi yaitu bergesernya penekanan dari pertobatan kepada tanggung jawab sosial, pemberitaan diganti dengan dialog. Akan tetapi

\footnotetext{
${ }^{3}$ Dave Hagelberg, Makalah Seminar Ilmu Misi Modern (Yogyakarta: STTII, 1982).

${ }^{4}$ Susanto, Perjanjian Baru Interlinier Yunani-Indonesia Dan Korkondansi Perjanjian Baru (PBIK) - Jilid

1.

${ }^{5}$ Oni, "Prinsip Perintah Yesus Untuk Menjadikan Murid Berdasarkan Matius 28:16-20," HUPERETES: Jurnal Teologi dan Pendidikan Kristen 1, no. 2 (2020): 140-149.

${ }^{6}$ Fransiskus Irwan Widjaja, Daniel Ginting, and Sabar Manahan Hutagalung, "Teologi Misi Sebagai Teologi Amanat Agung," Tronos: Jurnal Teologi Kristen 1, no. 1 (2019).
} 
ketegangan pemahaman di atas harus dipahami dalam konteks yang lebih luas dan bukannya saling meniadakan satu dengan yang lainnya, bahwa penyampaian Injil penting. Namun di sisi lain, tanggung jawab sosial juga diperlukan sehingga tidak perlu dipertentangkan kedua hal tersebut.

Kisah Para Rasul 1:8 menyanjikan frasa "kamu akan menjadi saksiKu..." Frasa ini menunjukkan bahwa misi harus dipahami dalam rangka kesaksian dan pelayanan dan keterlibatan sosial. Selanjutnya mengacu pada Yesaya 6:1-3 dan 2 Korintus 5:18-19, menyatakan bahwa misi gereja merupakan perpaduan dua tipe yaitu misi gereja dalam rangka perdamaian tetapi pada pihak lain misi gereja dalam rangka memberitakan pembebasan dari tawanan dan meneguhkan orang yang remuk hati. Namun di atas semuanya itu yang paling utama dalam misi Amanat Agung Tuhan Yesus Kristus adalah Proklamasi Injil Yesus Kristus, pertobatan, dan penanaman gereja. ${ }^{7}$

Kata "segala kuasa" menunjuk kepada umat Allah yang dijanjikan wewenang dan kuasa untuk memberitakan Injil di seluruh dunia. ${ }^{8}$ Tetapi murid-murid Tuhan Yesus harus menaati perintah Kristus yaitu menantikan janji Bapa yaitu kuasa Roh Kudus pada hari Pentakosta. Kata-kata ini merupakan Amanat Agung Tuhan Yesus Kristus kepada semua pengikutNya dari setiap angkatan. Amanat ini menyatakan sasaran, tanggung jawab, dan penugasan gereja dalam tugas misionernya. Gereja harus pergi ke seluruh dunia untuk memberitakan Injil kepada semua orang sesuai dengan penyataan Perjanjian Baru tentang Kristus dan ajaran para rasul-Nya (Ef. 2:20). Tugas ini termasuk kewajiban utama yaitu mengirim utusan gerejani ke setiap bangsa di dunia (Kis. 13:1-4). Injil yang diberitakan berpusat pada pertobatan dan pengampunan dosa (Luk. 24:47), janji penerimaan karunia Roh Kudus (Kis. 2:38) dan nasehat untuk memisahkan diri dari angkatan yang jahat ini (Kis. 2:40), sambil menantikan kedatangan Kristus dari Sorga (Kis. 3:19-20; 1Tes. 1:10).

Janji wewenang dan kuasa yang diberikan dalam memberitakan Injil di atas, sejatinya menjadi pemicu semangat dan motivasi setiap orang percaya. Namun janji ini belum diyakini sepenuhnya. Seperti yang diungkapkan oleh Edwin Gandaputra Yen, kendala Penginjilan pribadi dalam menjalankan Amanat Agung Tuhan Yesus terbesar adalah ketakutan dan ketidakmampuan dalam penginjilan pribadi. ${ }^{9}$ Kendala dapat menjadi lebih mudah diatasi, jika seorang memiliki pemahaman yang tepat tentang Amanat Agung Tuhan Yesus, terlebih jika meyakini akan janji penyertaan Tuhan. Tujuan penulisan ingin memberikan pemikiran yang mendalam antara pemberitaan Injil yang dimaknai sebagai misi utama dengan istilah Amanat Agung, dengan tindakan sosial yang belakangan dicurigai telah menggeser intisari misi (perintah amanat agung). Di samping itu, reintepretasi teks dalam Injil Matius 28:18-20 sebagai Amanat Agung ditempatkan sebagai perintah agung yang sama agungnya dengan perintah Tuhan Yesus di bagian lain dalam Alkitab, sehingga umat dan pembaca memiliki pemahaman teologis secara komprehensif.

\footnotetext{
${ }^{7}$ Richard AD Siwu, Misi Dalam Pandangan Ekumenikal Dan Evangelikal Asia (Jakarta: BPK Gunung Mulia, 1996), 298-299.

${ }^{8}$ Susanto, Perjanjian Baru Interlinier Yunani-Indonesia Dan Korkondansi Perjanjian Baru (PBIK) - Jilid 1 .

${ }^{9}$ Edwin Gandaputra Yen, “Tinjauan Ulang Penginjilan Pribadi Dalam Kerangka Amanat Agung Tuhan Yesus Melalui Eksposisi Matius 28:19-20” 5, no. 1 (2019): 31-48.
} 


\section{Metode Penelitian}

Penelitian merupakan cara ilmiah untuk mendapatkan data dengan tujuan dan kegunaan tertentu. Penelitian adalah kegiatan aktif dan proses sistematis untuk mendapatkan temuan baru atau ilmu, interpretasi serta memperbarui fakta. Tolak ukur dari penelitian adalah melakukan deskripsi dari informasi yang dihasilkan dan berkaitan dengan standar ilmiah. ${ }^{10}$ Tipe penelitian ini yaitu kualitatif deskriptif, karena pada penelitian ini membahas dan bertujuan untuk menghasilkan suatu pemahaman teologis mengenai pengaruh pemahaman amanat agung dengan menggali, mendeskripsikan, dan menafsirkan kembali. Metode analisis deskriptif juga menentukan pengolahan data serta literatur untuk dideskripsikan kemudian dianalisis untuk menemukan kesimpulan.

\section{Pembahasan}

Pemikiran Susanto mengenai Amanat Agung dapat dijadikan jembatan untuk memahami konsep misi yang dapat disampaikan kepada gereja dan umat secara keseluruhan, dan Kristus yang menjadi pusat pemuridan, oleh karena pemuridan adalah perintah utama. ${ }^{11}$ Selanjutnya sebagaimana dipaparkan oleh Bartholomeus, tugas Amanat Agung adalah tugas pemuridan yang kadang sulit dilakukan. Dari dua pemikir ini bersepakat bahwa pemuridan adalah hal yang esensial dalam amanat agung Matius 28:18-20. ${ }^{12}$ Pada pembahasan artikel ini pendekatan penulis lebih kepada memaknai Matius 28: 18-20 sebagai salah satu Amanat Agung dan bukan satu-satunya Amanat Agung Tuhan Yesus. Berikut Matius 28:18-20 dalam tiga terjemahan, sebagai berikut:

\begin{tabular}{|c|c|c|}
\hline Terjemahan Baru & King James Version & Greek New Testament \\
\hline $\begin{array}{l}\text { Yesus mendekati mereka dan } \\
\text { berkata: "Kepada-Ku telah } \\
\text { diberikan segala kuasa di sorga } \\
\text { dan di bumi. Karena itu } \\
\text { pergilah, jadikanlah semua } \\
\text { bangsa murid-Ku dan baptislah } \\
\text { mereka dalam nama Bapa dan } \\
\text { Anak dan Roh Kudus, dan } \\
\text { ajarlah mereka melakukan } \\
\text { segala sesuatu yang telah } \\
\text { Kuperintahkan kepadamu. Dan } \\
\text { ketahuilah, Aku menyertai } \\
\text { kamu senantiasa sampai kepada } \\
\text { akhir zaman. }\end{array}$ & $\begin{array}{l}\text { And Jesus came and spake unto } \\
\text { them, saying, All power is } \\
\text { given unto me in heaven and in } \\
\text { earth. Go ye therefore, and } \\
\text { teach all nations, baptizing them } \\
\text { in the name of the Father, and } \\
\text { of the Son, and of the Holy } \\
\text { Ghost: Teaching them to } \\
\text { observe all things whatsoever I } \\
\text { have commanded you: and, lo, I } \\
\text { am with you always, even unto } \\
\text { the end of the world. Amen }\end{array}$ & 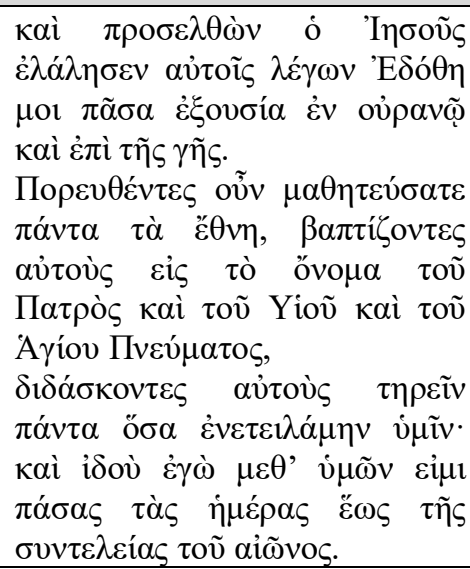 \\
\hline
\end{tabular}

Ayat di atas adalah ayat yang sangat sering orang percaya dengar yang kemudian orang percaya sebut sebagai “Amanat Agung." Peristiwa kenaikan Tuhan Yesus ke Surga yang orang percaya peringati ini tidak bisa dipisahkan dari Amanat Agung Tuhan Yesus. Ini adalah pesan terakhir Yesus sebelum naik ke Surga. Pada kesempatan ini orang percaya akan

\footnotetext{
${ }^{10}$ Sutan Surya, Panduan Menulis Skripsi, Tesis, Disertasi Dan Karya Ilmiah (Yogyakarta: Pustaka Pena, 2006), 3

${ }^{11}$ Susanto Dwiraharjo, "Kajian Eksegetikal Amanat Agung Menurut Matius 28 : 18-20," Jurnal Teologi Gracia Deo 1, no. 2 (2019): 56-73, http://sttbaptisjkt.ac.id/e-journal/index.php/graciadeo.

${ }^{12}$ Bartholomeus Diaz Nainggolan, "Pemahaman Konsep Dan Keterlibatan Dalam Penginjilan Berdasarkan Matius 28:18-20," JURNAL KOINONIA 8, no. 2 (2016): 35-70.
} 
mengupas Amanat Agung Tuhan Yesus ini dengan lebih seksama. Seseorang dapat menolak melakukan misi dengan berbagai alasan, namun tidak beralasan lagi apabila misi sudah menjadi suatu amanat (perintah). ${ }^{13}$ Ketika membaca Matius 28:19-20, ada empat Amanat Agung Tuhan Yesus (P4), yaitu: penginjilan, pemuridan, pembaptisan, dan pengajaran. Seringkali tidak disadari bahwa pelayanan tidak memberitakan Injil seperti yang Tuhan Yesus inginkan melainkan hanya membuat pengaruh kepada orang yang ada di sekeliling saja. Memberitakan Injil (penginjilan) bersifat perorangan maupun berkelompok, yang kemudian jika orang itu menjadi percaya maka dia adalah murid (pemuridan).

Salah satu dasar misi Kristen adalah Amanat Agung atau Perintah Agung dari Tuhan Yesus Kristus. Namun kata perintah dalam Amanat Agung yang tertera pada Matius 28: 1920 adalah entello yang berarti perintah untuk bergabung dengan sesuatu atau perintah untuk terikat pada sesuatu. Konteksnya jelas yaitu bergabung dan terikat pada misi Amanat Agung Kristus. Suatu misi yang dilakukan Yesus Kristus untuk menyelamatkan manusia dari akibat kuasa dosa. ${ }^{14}$ Amanat Agung Kristus tersebut menggunakan bentuk partisip, sehingga amanat tersebut menjadi suatu kewajiban bagi setiap orang percaya. Bosch menekankan bahwa Amanat Agung pada akhir Injil Matius harus dipahami sebagai kunci menuju pemahaman Matius tentang misi dan pelayanan Yesus. ${ }^{15}$ Dengan demikian, Amanat Agung erat kaitannya dengan implementasi dari pelayanan Yesus di dunia ini.

Kuasa Tuhan Yesus memulai perintahnya dengan suatu pernyataan, suatu deklarasi yang menjadi fondasi. Dalam teks Matius tersebut, Tuhan Yesus mengatakan, "Kepada-Ku telah diberikan segala kuasa." Menurut kamus, kata "kuasa" diterjemahkan dari bahasa Yunani exousia. ${ }^{16}$ Lebih jelas jika digunakan kata moderen otoritas (authority), berbeda dengan kata kuasa yang digunakan dalam Kisah Rasul 1:8, di mana Yesus berkata "Tetapi kamu akan menerima kuasa, kalau Roh Kudus turun ke atas kamu." Kata kuasa pada ayat terakhir ini terjemahan dari kata dunamis. Kata "kuasa" seperti yang dibahas di atas, dalam Amanat Agung menunjukkan Yesus sebagai pemilik otoritas, atau berkuasa atas muridmuridnya dan memiliki hak untuk mendapatkan sikap taat dari murid-muridnya. Kenaikan Yesus ke Sorga untuk duduk di sebelah kanan Allah Bapa, jauh lebih tinggi dari segala pemerintahan, kuasa dan kekuasaan di dunia ini dan di dunia yang akan datang (Ef. 1:20, 21), supaya dalam nama Yesus bertekuk lutut segala yang ada di langit dan yang ada di atas bumi dan yang ada di bawah bumi, dan segala lidah mengaku "Yesus Kristus adalah Tuhan" (Flp. 2:10-11).

Penekanan Amanat Agung dalam Matius 28:17-20 adalah para murid dalam keadaan lemah iman untuk melakukan misi. Hal ini terlihat dari latar belakang situasi pada saat itu. Para murid dalam keadaan takut, ketidakpastian, bingung, masih memiliki pola pikir yang keliru terhadap kematian Kristus disalib. ${ }^{17}$ Konsekuensi dari hal ini, orang percaya yang mengaku sebagai murid-murid Yesus tidak punya pilihan selain mentaati dan menjalankan

\footnotetext{
${ }^{13}$ Putranto, Misi Kristen, 8.

${ }^{14}$ Ibid., 58.

${ }^{15}$ David J. Bosch, Transformasi Misi Kristen (Jakarta: BPK Gunung Mulia, 1999), 93.

${ }^{16}$ Susanto, Perjanjian Baru Interlinier Yunani-Indonesia Dan Korkondansi Perjanjian Baru (PBIK) -

${ }^{17}$ Hagelberg, Makalah Seminar Ilmu Misi Modern.
} Jilid 1 . 
Amanat Agung ini. Seperti seorang Jenderal yang memberikan perintah kepada bawahannya, jika bawahannya tidak mentaati perintah tersebut maka bawahannya melanggar perintah dan harus bertanggung jawab.

Amanat Agung adalah perintah, bukan permintaan, permohonan, nasehat, saran atau himbauan. Tujuan utama adalah Menjadikan Murid. Kalimat berikutnya pada ayat 19 sebagai berikut: "Karena itu pergilah, jadikanlah semua bangsa murid-Ku dan baptislah mereka dalam nama Bapa dan Anak dan Roh Kudus, dan ajarlah mereka melakukan segala sesuatu yang telah Kuperintahkan kepadamu." Dalam bahasa sederhana, Amanat Agung berbunyi: "Jadikanlah semua bangsa murid-Ku, caranya "Pergilah", "Baptislah" dan "Ajarlah." Jadi, fokus Amanat Agung adalah menjadikan semua bangsa murid Yesus! Pergi, membaptis, dan mengajar, bukanlah tujuan utama dari Amanat Agung, melainkan metode, cara, atau kegiatan dari "menjadikan murid." Bagian terakhir Amanat Agung menyebutkan perintah "ajarlah mereka melakukan segala sesuatu yang telah Kuperintahkan kepadamu" (Mat. 28:20). Perintah "ajarlah mereka", dan perintah "baptislah mereka" tampaknya merupakan isi yang sesungguhnya dari upaya pemuridan. ${ }^{18}$

Berkaitan dengan Amanat Agung yang merujuk kepada Matius 28:19 dan berdasarkan kenyataan peristiwa yang tertulis dalam Injil dan Kisah Para Rasul, bahwa Amanat Agung dan baptisan adalah dua hal yang saling bersinergis. ${ }^{19}$ Para murid bukan hanya memberitakan Injil kepada segala bangsa tetapi juga telah menerima mereka yang datang untuk dibaptis dalam nama Yesus dan mereka yang dibaptis dan yang membaptis keduanya telah menerima Roh Kudus. Perlu diingat cara dan tujuan perintah Amanat Agung ini adalah dua sisi berbeda dari satu koin yang sama. Sisi yang satu tidak bisa ada tanpa sisi yang lain. Jika jemaat melakukan aktifitas "pergi", "baptis" dan "mengajar" tanpa tujuan untuk menjadikan murid berarti melanggar tujuan esensial dari Amanat Agung. Di sisi lain, jika jemaat menjadikan bangsa murid tanpa melakukan "pergi", "'baptis", dan "mengajar", maka upaya tersebut belum lengkap dalam mengimplementasikan Amanat Agung.

Kata "pergilah" mengindikasikan dua makna. Makna pertama, berkaitan dengan konsep penginjilan. Adalah hal yang sulit untuk menjadikan orang yang belum Kristen menjadi murid Yesus. Berkaitan dengan kondisi seperti ini, Putranto menjelaskan bahwa para murid mendapat kuasa untuk melakukan misi. Tuhan memahami kelemahan para murid, oleh karena itu Tuhan memberi kuasa dan kemampuan untuk melaksanakan misi agung yang diperintahkan-Nya. ${ }^{20}$ Jadi, langkah pertama adalah memperkenalkan orang kepada Yesus dan mengalami kelahiran baru.

Makna kedua, kata "pergilah" menunjukkan bahwa orang percaya harus mengambil insiatif untuk bergerak dan pergi. ${ }^{21}$ Amanat Agung tidak akan bisa dipenuhi jika orang percaya hanya diam saja atau pasif. Tuhan Yesus dengan jelas memerintahkan orang percaya untuk bersikap aktif, tidak hanya menjadi penonton. Hal ini dapat berarti pergi ke pedalaman, ke luar negeri, ke bangsa-bangsa atau juga pergi ke rumah tetangga di seberang jalan. Yang

\footnotetext{
${ }^{18}$ Bosch, Transformasi Misi Kristen, 102.

${ }^{19}$ Nur Fitriyana dan Murtiningsih, "Matius $28: 19$ Analisis Hermeneutik Dalam Tafsiran Alkitab Masa Kini,” Jurnal Ilmu Agama 20, no. 2 (2019): 235-261.

${ }^{20}$ Putranto, Misi Kristen, 59.

21 Ibid.
} 
penting adalah anda mengambil inisiatif, proaktif, bergerak, pergi! Kata "baptislah" menunjuk kepada cara baptis selam seperti yang dilakukan oleh gereja mula-mula. Tetapi dalam kaitannya dengan Amanat Agung, maka ada beberapa hal yang perlu diperhatikan. Ketika seseorang melakukan baptisan, maka ia menyatakan secara terbuka kepada dunia ini bahwa ia sudah menjadi bagian dari Kerajaan Allah (Ef. 4:3-6). Ketika ia ditenggelamkan dan dibangkitkan kembali dari dalam air, ia sedang mengidentifikasikan diri dengan kematian, penguburan, dan kebangkitan orang percaya Tuhan Yesus. Para Murid diarahkan pada sasaran misi. Yesus Kristus sebagai Guru Agung memahami ketidaktahuan para murid. Oleh karena itu, Ia mengarahkan sasaran misi pada para murid, baptislah mereka dalam nama Bapa dan Anak dan roh Kudus, dan ajarlah mereka melakukan segala sesuatu yang telah $\mathrm{Ku}$ perintahkan kepadamu. $^{22}$

Terkait Amanat Agung di atas, masa gereja mula-mula, tindakan baptisan air dapat membawa cemoohan, penganiayaan hingga kematian dari orang-orang yang belum percaya dan beberapa daerah di dunia. Hal ini pun masih terjadi hingga kini. Pada masa itu baptisan air adalah harga yang mahal yang harus dibayar bagi seseorang untuk bisa menyatakan bahwa ia adalah murid Yesus. Dalam kaca mata Amanat Agung, Yesus memerintahkan orang percaya untuk menjadikan murid dengan cara menolong mereka dikenal secara terbuka sebagai milik-Nya. Selain identifikasi sebagai milik Yesus, baptisan air juga deklarasi masuknya orang tersebut sebagai anggota keluarga Allah atau jemaat Allah. Ia menyatakan kepada dunia bahwa ia sekarang ada dipihak murid-murid Kristus. Ada implikasi penting dari hal ini yang sering dilupakan oleh umat. Setelah seseorang dibaptis, akan diterima sebagai anggota keluarga oleh jemaat. Kemudian benar-benar menjadi anggota keluarga dan jemaat memiliki tanggung jawab sebagaimana layaknya keluarga. Hal ini merupakan tugas gereja atau jemaat untuk pergi kepada semua orang dan menjadikan mereka sebagai bagian dari komunitas iman. ${ }^{23}$ Jadi, tidak cukup hanya menjabat tangan dan memberi selamat kepada mereka setelah dibaptis tetapi menjadi anggota dalam komunitas iman dalam jemaat.

Jika seseorang disebut murid, logikanya ada sesuatu yang dipelajari dan ada yang mengajarkannya. Mengajar yang dimaksud dalam hal ini bukan sekedar pengetahuan saja, tetapi pengajaran yang membawa tindakan yang kemudian membawa perubahan. Kalimat lengkapnya adalah "Ajarlah mereka melakukan segala sesuatu yang telah Kuperintahkan kepadamu" (Mat. 28:20). Di lain pihak tugas orang percaya tidak berhenti ketika seseorang menerima pengajaran, tidak peduli seberapa banyak pengajaran yang ia terima, jika orang tersebut belum melakukan apa yang sudah diajarkan tersebut. George W. Peters menjelaskan bahwa dalam Amanat Agung Tuhan Yesus nampaknya tekanan terletak pada pengajaran. Karena itu, jemaat mula-mula bertekun dalam pengajaran rasul-rasul, atau dengan kata lain, mereka datang setiap hari untuk mendengar pengajaran rasul-rasul. ${ }^{24}$

Menurut hemat peneliti, secara umum ada tiga langkah yang harus dilakukan dalam hal ini. Langkah pertama tentunya tindakan belajar itu sendiri. Langkah ini meliputi perpindahan

${ }^{22}$ Ibid.

${ }^{23}$ I Putu Ayub Darmawan, "Jadikanlah Murid : Tugas Pemuridan Gereja Menurut Matius 28 : 18-20,"

Evangelikal: Jurnal Teologi Injili dan Pembinaan Warga Jemaat 3, no. 2 (2019): 144-153, https://journal.sttsimpson.ac.id/index.php/EJTI/article/view/138.

${ }^{24}$ George W. Peters, Teologi Pertumbuhan Gereja (Malang: Gandum Mas, 2002), 232. 
informasi yang menghasilkan adanya pengetahuan atau diistilahkan head knowledge. Tetapi bukan sekedar pengetahuan sebagai fakta tetapi pengetahuan yang dimengerti secara sungguh-sungguh. Jadi, bukan hanya membaca tetapi juga ada proses perenungan yang berulang-ulang, menyeluruh dan sistematis (Ul. 6:6, 7).

Langkah kedua adalah mencintai. Tidak cukup hanya mengerti dengan sungguhsungguh, tetapi seseorang harus mencintai pengajaran Yesus sehingga percaya dan mengimaninya dengan sungguh-sungguh atau diistilahkan heart knowledge (Mzm. 1:2). Putranto menerangkan, Injil Markus menyatakan bahwa para murid mendapat kuasa untuk melakukan misi amanat agung, namun penekanannya dalam bentuk akan diselamatkan atau dihukum. Siapa yang percaya dan dibaptis akan diselamatkan, tetapi siapa yang tidak percaya akan dihukum. ${ }^{25}$ Langkah ketiga adalah melakukan. Jika rasa cinta akan pengajaran Tuhan Yesus sudah terbentuk, maka langkah ketiga adalah melakukan pengajaran tersebut dalam kehidupan sehari-hari, hand knowledge. Sesuai dengan Amanat Agung ini, pemimpin jemaat diwajibkan untuk menjaga dan memberi makan kawanan domba (Kis. 20:28). Tetapi hal yang menarik untuk direnungkan ialah jika gembala diharuskan untuk memberi makan, bukankah domba-domba diharuskan untuk makan?

Umumnya, jemaat memiliki pemahaman bahwa kewajiban mereka adalah pergi ke gereja pada hari Minggu, memberi persembahan, dan mengikuti Perjamuan Kudus. Kegiatan sisanya sekadar pilihan saja, tergantung dari keinginan, kesibukan atau sekedar rasa sungkan. Padahal, gereja Tuhan sudah mempersiapkan banyak sarana bagi jemaat untuk belajar dan bertumbuh. Anggapan bahwa menjadi orang Kristen tidak perlu belajar adalah anggapan keliru. Sebaliknya, umat Tuhan harus giat belajar agar memiliki pemahaman yang memadai tentang kebenaran. Orang percaya sebagai orang-orang yang diberi karunia untuk mengaku sebagai murid-murid Kristus memiliki kewajiban untuk melaksanakan perintah dari Raja di atas segala raja, Tuhan di atas segala Tuhan, Pencipta Alam Semesta yang sudah mati untuk menebus dosa orang percaya yaitu Yesus Kristus. Tuhan Yesus memberikan perintah, Ia juga sudah memberikan kepada orang percaya segenap hal yang diperlukan untuk melaksanakan perintah tersebut, ingat perumpamaan mengenai talenta (Mat. 25:14-30). Jadi, tidak ada alasan bagi orang percaya untuk tidak melaksanakan Amanat Agung. Ini bukan hanya tugas dari pendeta, gembala atau pelayan Tuhan saja, ini adalah tugas semua orang percaya.

Amanat agung adalah wadah refleksi karunia yang saling melengkapi dalam melakukan pekerjaan Tuhan. ${ }^{26}$ Menunaikan Amanat Agung yang telah diberikan kepada orang-orang percaya, sesederhana apapun tugas tersebut di mata manusia, tetapi di mata Allah sangat berharga. Peringatan Yesus pada saat orang percaya menyia-nyiakan talenta yang sudah diberikan kepada orang percaya (Mat. 25:29-30). James Kennedy menegaskan bahwa setiap orang Kristen bertanggung jawab untuk menyatakan Injil dalam kehidupan sehari-hari. ${ }^{27}$ Ketika orang percaya memberitakan Injil kepada semua orang, maka Tuhan turut bekerja dan meneguhkan Firman itu dengan tanda-tanda ajaib yang menyertainya sehingga terjadi banyak

${ }^{25}$ Putranto, Misi Kristen, 61.

${ }^{26}$ Handreas Hartono, "Mengaktualisasikan Amanat Agung Matius 28 : 19-20 Dalam Konteks Era

Digital," KURIOS (Jurnal Teologi dan Pendidikan Agama Kristen) 4, no. 2 (2018): 19-20, www.sttpb.ac.id/ejournal/index.php/kurios.

${ }^{27}$ James Kennedy, Ledakan Penginjilan (Jakarta: EE International, n.d.), 12. 
mujizat: menyembuhkan orang sakit, membangkitkan orang mati, mentahirkan orang kusta, mengusir setan-setan, berbicara dalam bahasa yang baru, tidak mendapat celaka sekalipun meminum racun maut. Para murid mendapat jaminan penyertaan Kristus sampai akhir zaman. Ini suatu jaminan bahwa amanat misi yang diperintahkanNya serius, urgen, genting, mendesak harus dilaksanakan karena menyangkut keselamatan jiwa-jiwa manusia. ${ }^{28}$

Melaksanakan Amanat Agung Tuhan Yesus bukan hal yang mudah, namun orangorang Kristen tidak perlu berkecil hati. Mengapa? Karena Kristus sendiri yang menyatakan janji. Janji tersebut berbunyi, "Dan ketahuilah, Aku menyertai kamu senantiasa sampai kepada akhir zaman." Janji penyertaan Kristus bukan suatu janji yang kosong, karena selain Dia telah lahir dalam hidup kita (Mat.1:23), tapi Dia juga Allah yang berkuasa. Sebelum memberikan Amanat Agung kepada murid-murid-Nya, Dia sendiri mengklaim, yaitu "Kepada-Ku telah diberikan segala kuasa di sorga dan di bumi." Ungkapan "sorga dan bumi" menyatakan wilayah kekuasaan Kristus yang begitu luas dan tanpa batas, sehingga tidak ada satu tempat di mana kuasa Kristus tidak bisa menjangkau. Kemanapun orang Kristen pergi memberitakan Injil, disitulah Kristus hadir dan menyatakan kuasa-Nya. Injil Yohanes menyatakan para murid mendapat perlengkapan rohani untuk melakukan Amanat Agung Tuhan Yesus. Tuhan memberi perlengkapan rohani melalui kehadiran Roh Kudus yang diembuskan pada murid-murid. ${ }^{29}$ Tidak hanya kuasa dan perlengkapan saja, Yohanes menekankan wewenang untuk para murid dengan menyatakan, "Jikalau kamu mengampuni dosa orang, dosanya diampuni, dan jikalau kamu menyatakan dosa orang tetap ada, dosanya tetap ada. Melalui wewenang itu akan ada dampak seorang yang menolak Injil akan berdosa." ${ }^{30}$ Selain itu, diperlukan juga kebangkitan rohani dalam menjalankan Amanat Agung. Seperti yang ditegaskan oleh Camerling dan Wijaya, kebangkitan rohani dapat menghidupkan kembali gairah untuk bermisi, dan misi adalah salah satu langkah yang kongkret. ${ }^{31}$ Untuk itu, tanda-tanda yang muncul saat kebangkitan rohani terjadi adalah hati misi ikut di dalamnya.

\section{Hasil Temuan}

Tujuan pemberitaan Injil dalam amanat agung Matius 28 adalah untuk memuridkan orang percaya yang akan menaati semua perintah Kristus. Inilah satu-satunya perintah langsung dalam ayat ini. Kristus tidak bermaksud bahwa penginjilan dan kesaksian para utusan gerejani hanya menghasilkan keputusan untuk bertobat dan bukan sekedar untuk memperbanyak jumlah anggota gereja, tetapi untuk memuridkan setiap orang yang bersedia memisahkan diri dari dunia ini, menaati perintah-perintah Kristus serta mengikut Tuhan Yesus Kristus dengan segenap hati (Yoh. 8:31). Sesuai dengan yang sudah penulis paparkan di awal, dalam pembahasan hampir semua artikel jurnal menitikberatkan dalam pemuridan sebagai inti Amanat Agung Tuhan Yesus. Hal ini sudah banyak dibahas tapi dalam tulisan ini hanya menjelaskan sedikit soal ini dan lebih menggunjingkan pada hal esensi semua perkataan dan pemikiran Tuhan Yesus dengan perlunya memaknai Amanat Agung.

\footnotetext{
${ }^{28}$ Putranto, Misi Kristen, 60.

${ }^{29}$ Ibid., 65.

${ }^{30}$ Ibid.

${ }^{31}$ Yosua Camerling and Hengki Wijaya, "Misi Dan Kebangkitan Rohani: Implikasi Misi Allah Bagi Gereja,” Jurnal Ilmiah Religiosity Entity Humanity (JIREH) 1, no. 1 (2019): 57-71.
} 
Selanjutnya perlu diperhatikan bahwa Kristus memerintahkan setiap orang percaya untuk memusatkan perhatian untuk menjangkau jiwa-jiwa yang terhilang dan bukan untuk mengkristenkan masyarakat atau menguasai dunia ini. Orang percaya harus meninggalkan sistem dunia yang jahat ini. (Rm. 13:12; 2 Kor. 6: 14). Setiap orang yang percaya kepada Kristus harus dibaptis sebagai ikrar untuk meninggalkan semua perangai yang berdosa, dan dengan terang-terangan mengabdi kepada Kristus (Kis. 22:16). Kristus akan senantiasa mendampingi para pengikut Kristus melalui kehadiran dan kuasa Roh Kudus (Mat. 28:20; 18:20). Setelah orang percaya diperlengkapi dengan kekuasaan dari tempat yang tinggi, barulah pergi kepada semua bangsa di dunia untuk bersaksi (Luk. 24:49; Kis. 1:8).

Kata "Aku menyertai kamu" dalam Amanat Agung merupakan jaminan Kristus bagi orang percaya yang terlibat dalam menjangkau jiwa-jiwa yang terhilang. Yesus Kristus sudah bangkit dari kematian dan kini hidup serta secara pribadi selalu memperhatikan orang percaya melalui karya Roh Kudus (Yoh. 14:16,26) dan melalui Firman-Nya (Yoh. 14:23). Roh Kudus ikut ambil bagian dalam pelaksanaan misi amant agung Tuhan Yesus Kristus, dengan jalan menginsafkan dunia dari dosa (Yoh. 16:8-10), membuka hati manusia yang telah dibutakan kegelapan (2Kor. 4:4; Yoh. 15:26), melahirkan kembali orang percaya (Ef. 2:1,4-5), memeteraikan orang percaya sebagai milik Allah (2Kor. 1:22; Ef. 1:13; 4:30), meyakinkan orang percaya sebagai milik Allah (Rm. 8:16).

Berkaitan dengan penyertaan Tuhan dalam menjalankan Amanat Agung, Dwiraharjo menegaskan penyertaan Tuhan akan senantiasa tinggal tetap sekalipun waktu ini sudah berlalu. Waktu ini akan berakhir dan berganti dengan waktu yang baru, dan di situ jugalah penyertaan Tuhan tetap. ${ }^{32}$ Kebenaran ini seharusnya mendorong orang percaya untuk terus menerus melaksanakan Amanat Agung Tuhan ini sampai berakhirnya waktu yang Tuhan berikan atas hidup orang percaya. Ia memberikan suatu perintah yang harus dikerjakan dengan menjamin kehidupan mereka disertai oleh-Nya dan campur tangan-Nya selalu bersama dengan mereka. ${ }^{33}$ Mereka akan disertai selamanya sebab apa yang mereka akan lakukan adalah tugas besar yang harus dikerjakan sepanjang zaman. Dengan demikian, melaksanakan Amanat Agung merupakan kewajiban orang percaya dan jaminan akan penyertaan Tuhan.

\section{Kesimpulan}

Diskursif Amanat Agung Tuhan Yesus Kristus adalah salah satu puncak dari semua dasar Alkitab bagi pekabaran Injil untuk menumbuh-kembangkan iman yang bersumber pada ke empat Injil dan Kisah Para Rasul dengan penekanan yang berbeda-beda. Injil Matius 28:18-20 menekankan, para murid yang dalam keadaan lemah iman diberi kuasa untuk melakukan penginjilan dengan janji penyertaan Tuhan sampai akhir zaman. Injil Markus 16:14-18 menekankan pemberian kuasa kepada murid untuk melakukan penginjilan dengan menggunakan metode misi yang disertai dengan tanda-tanda. Injil Lukas 24: 44-49 menekankan bahwa para murid diberi hikmat dalam melakukan pekabaran Injil dalam menjangkau setiap suku. Injil Yohanes 20:19-23 menekankan para murid mendapat perlengkapan rohani untuk melakukan

\footnotetext{
32 Dwiraharjo, "Kajian Eksegetikal Amanat Agung Menurut Matius 28 : 18-20.”

${ }^{33}$ Patrecia Hutagalung, "Pemuridan Sebagai Mandat Misi Menurut Matius 28:18-20," Pengarah: Jurnal Teologi Kristen 2, no. 1 (2020): 64-76.
} 
pemberitaan Injil dengan wewenang dari Tuhan. Kisah Para Rasul 1:8 menekankan pemberian kuasa kepada para murid untuk menjadi saksi Kristus dengan strategi misi dari tempat yang terdekat berkembang ke tempat yang jauh (Yerusalem, Yudea, Samaria, dan sampai keujung bumi). Bahkan keseluruhan perkataan dan pemikiran Tuhan Yesus dalam Kitab Suci tidak hanya pada keempat Injil dan Kisah Para Rasul adalah Amanat Agung, oleh karena yang menyampaikan pemikiran dan memperkatakannya adalah Pribadi Yang Agung, sehingga apapun yang dikatakan adalah Amanat Agung bagi seluruh orang percaya.

\section{Referensi}

Bosch, David J. Transformasi Misi Kristen. Jakarta: BPK Gunung Mulia, 1999.

Camerling, Yosua, and Hengki Wijaya. "Misi Dan Kebangkitan Rohani: Implikasi Misi Allah Bagi Gereja." Jurnal Ilmiah Religiosity Entity Humanity (JIREH) 1, no. 1 (2019): 5771.

Darmawan, I Putu Ayub. "Jadikanlah Murid : Tugas Pemuridan Gereja Menurut Matius 28 : 18-20.” Evangelikal: Jurnal Teologi Injili dan Pembinaan Warga Jemaat 3, no. 2 (2019): 144-153. https://journal.sttsimpson.ac.id/index.php/EJTI/article/view/138.

Dwiraharjo, Susanto. "Kajian Eksegetikal Amanat Agung Menurut Matius 28 : 18-20." Jurnal Teologi Gracia Deo 1, no. 2 (2019): 56-73. http://sttbaptisjkt.ac.id/ejournal/index.php/graciadeo.

Fitriyana, Nur. "Matius $28: 19$ Analisis Hermeneutik Dalam Tafsiran Alkitab Masa Kini." Jurnal Ilmu Agama 20, no. 2 (2019): 235-261.

Hagelberg, Dave. Makalah Seminar Ilmu Misi Modern. Yogyakarta: STTII, 1982.

Hartono, Handreas. "Mengaktualisasikan Amanat Agung Matius 28 : 19-20 Dalam Konteks

Era Digital.” KURIOS (Jurnal Teologi dan Pendidikan Agama Kristen) 4, no. 2 (2018):

19-20. www.sttpb.ac.id/e-journal/index.php/kurios.

Hutagalung, Patrecia. "Pemuridan Sebagai Mandat Misi Menurut Matius 28:18-20."

Pengarah: Jurnal Teologi Kristen 2, no. 1 (2020): 64-76.

Kennedy, James. Ledakan Penginjilan. Jakarta: EE International, n.d.

Nainggolan, Bartholomeus Diaz. "PEMAHAMAN KONSEP DAN KETERLIBATAN DALAM." JURNAL KOINONIA 8, no. 2 (2016): 35-70.

Oni. "Prinsip Perintah Yesus Untuk Menjadikan Murid Berdasarkan Matius 28:16-20." HUPERETES: Jurnal Teologi dan Pendidikan Kristen 1, no. 2 (2020): 140-149.

Peters, George W. Teologi Pertumbuhan Gereja. Malang: Gandum Mas, 2002.

Putranto, BE. Misi Kristen. Yogyakarta: Andi Offset, 2017.

Siwu, Richard AD. Misi Dalam Pandangan Ekumenikal Dan Evangelikal Asia. Jakarta: BPK Gunung Mulia, 1996.

Surya, Sutan. Panduan Menulis Skripsi, Tesis, Disertasi Dan Karya Ilmiah. Yogyakarta: Pustaka Pena, 2006.

Susanto, Hasan. Perjanjian Baru Interlinier Yunani-Indonesia Dan Korkondansi Perjanjian Baru (PBIK) - Jilid 1. Jakarta: Lembaga Alkitab Indonesia (LAI), 2006.

Widjaja, Fransiskus Irwan, Daniel Ginting, and Sabar Manahan Hutagalung. "Teologi Misi Sebagai Teologi Amanat Agung.” Tronos: Jurnal Teologi Kristen 1, no. 1 (2019).

Yen, Edwin Gandaputra. "Tinjauan Ulang Penginjilan Pribadi Dalam Kerangka Amanat Agung Tuhan Yesus Melalui Eksposisi Matius 28:19-20” 5, no. 1 (2019): 31-48. 